\title{
The Importance of Being Man: An Introduction to the Libertine Ideology
}

\author{
Tiziana Febronia Arena \\ University of Catania, Catania, Italy
}

\begin{abstract}
In this paper, I will examine the libertine ethos of the Restoration, a period of time characterized by an atmosphere in which promiscuity and extravagance became the norm. This ideology was based on individual liberty, hedonism and the gratification of one's senses. In order to show how libertinism contributed to develop male chauvinism, I will focus on how the male ideology which reduced woman to an object, a passive body, was fought by the lady cavaliers who became the active other. As Derrida argued men need to recognize woman's subjectivity in order to exist.
\end{abstract}

Keywords: Restoration, male sovereignty, Hobbes, différance, woman's body

The libertines were playwrights who embodied their own reputations in their libertine protagonists[...].

The libertines were themselves texts to be analyzed, interpreted, and valuated. - Jeremy Webster

Performing Libertinism in Charles II's Court, Politics, Drama, Sexuality (2005)

\section{Introduction}

After the 11 years, from 1649 to 1660, marked by the abortive experiment of the Republic, the king Charles II, "a tall, swarthy man with sensual lips and cynical eyes", ${ }^{1}$ returned to his native land. It was 1660.

Cromwell's suppression of Parliament in 1653 reduced the Lords' power, provoking their disaffection. Some of those noblemen worked for the return of the monarchy.

When Charles came back, the aristocracy welcomed and supported him. A new era was about to start:

A new Parliament, dominated by royalists, did all in its power to make it seem that the Interregnum had never been, even to dating the reign of Charles II from the death of Charles I. Regicides were executed; the bodies of Cromwell, Ireton, and Bradshaw were dug up and hung in chains; nonconformists were persecuted; the sumptuary laws of Cromwell's regime were repealed or ignored. ${ }^{2}$

Tiziana Febronia Arena, adjunct professor, Ph.D., Medical School, University of Catania.

1 John Harold Wilson. (1968). A preface to Restoration drama. Cambridge, Massachusetts: Harvard University Press, p. 1.

2 John Harold Wilson. (1948). The court wits of restoration, an introduction. Princeton, Princeton University Press, p. 3. 


\section{The Construction of a Monarch}

An extreme reaction to the severe Puritan rules dominated the Restoration of the Country. ${ }^{3}$

Rejecting all previous ideals, which essentially exalted the metaphysical, introspective, and private dimensions, immorality, amorality, and frivolity represented the values of this new reaction. ${ }^{4}$ Needless to say, libertines with their culture and literature would not exist without the Puritan Age. ${ }^{5}$

Civil war brought in England and in English life new attitudes in religion, politics, sexual relationships, and in scientific inquiry. ${ }^{6}$

The Reaction against Puritan manners and morals was inevitable. It was all the more violent because many of the Returned Cavaliers had spent their exiles in France and become expert in French wit and French gallantry, and because the king himself, an indolent sensualist possessed of both wit and cunning, encouraged an atmosphere of hedonistic liveliness at Court. ${ }^{7}$

As Wilson has written, "The King was the first of the Wits", ${ }^{8}$ involved in his person in the elite circle flourished from 1665 to 1680 . Charles felt it necessary to be recognized, in every way, as unique and specially different from his predecessors. For that reason, he created an atmosphere in which promiscuity and extravagance became the norm. ${ }^{9}$

In 1665, the young Earl of Rochester joined the group, becoming its leader in literature and devilry. The king and his friends, Wilmot, Buckingham, Etherege, Wycherly, and Sedley, formed the quintessence of the libertine circle. ${ }^{10}$ For their scandalous behaviours, they became protagonists of their society; their names were shouted out at theatre or whispered elsewhere. As Webster has pointed out:

Throughout Charles II's Reign, the libertine was a familiar figure as a sexual and as a radical questioner of social, political, and moral values. Not only was the libertine a dominant figure in the poems and plays of the Restoration period, but he was also a frequent subject of conversation in the alehouses and coffee shops of London, in the corridors of Whitehall and in the drawing rooms of country houses. ${ }^{11}$

As Webster notes, "shocking people with their excessive sexual postures and profane mimicry was just only one way"12 in which libertines loved expressing themselves, both in life and on the stage, creating "the libertine's reputation of debauchee, wit and scoundrel". ${ }^{13}$

They refused all parasitic authority: State, Church, and Family, which they considered illegitimate. ${ }^{14}$ As Chernaik has underlined:

${ }^{3}$ David Daiches. (1960). A critical history of English literature. London, Secker \& Warburg, Vol. III, p. 537.

${ }^{4}$ George Macaulay Trevelyan. (1964). Illustrated English social history. London, Pelican Books, Vol. II, p. 221.

${ }_{5}$ Melinda S. Zook. (2004). The political poetry of Aphra Behn. In Derek Hughes and Janet Todd (Eds), The Cambridge companion to Aphra Behn. Cambridge, Cambridge University Press, p. 46.

${ }^{6}$ G. M. Trevelyan. Illustrated English social history, op. cit., p. 217.

7 D. Daiches. A critical history of English literature, op. cit., p. 537.

8 J. H. Wilson. The court wits of restoration, op. cit., p. 5.

9 Ibidem.

${ }^{10}$ Ibidem.

11 J. W. Webster. Performing libertinism in Charles II's Court, op. cit., p. 2.

12 Ibid., p. 10.

13 Ibid., p. 12

14 Warren Chernaik. (1995). Sexual freedom in restoration literature. Cambridge: Cambridge University Press, p. 25. 
Libertinism is a young man's philosophy, a rebellion of the sons against the fathers. The conventional, middle-aged virtues - discretion, prudence, responsibility, the patient accumulation of wisdom or the worldly goods - are rejected out of hand as suitable only to those whose senses have been dulled by age or natural incapacity. ${ }^{15}$

Not only was Libertinism a way of writing, but it was also a lifestyle of the sons of the British Noblesse. Influenced by French ideals and manners, they embodied the alternative culture of the young Cavaliers regarded as cynical and Epicurean. Their Hedonistic credo was woman, wine, and song; their only goal was the gratification of their own senses. ${ }^{16}$ Rochester illustrated this in his song, Love a Woman:

Farewel Woman, I intend,

Henceforth, ev'ry Night to sit

With my lewd well natur'd Friend,

Drinking, to engender Wit.

Then give me Health, Wealth, Mirth, and Wine,

And if busie Love intrenches,

There's sweet soft Page, of mine,

Does the trick worth Forty Wenches. ${ }^{17}$

They found an instrument to interpret human conduct in Thomas Hobbes' doctrine, where selfishness and individualism were the dogmas of his system. ${ }^{18}$ The Restoration world was one of natural conflicts; explained through Hobbes' postulate — homo homini lupus — brothers and sisters, sons and fathers are natural rivals, both on the stage and in real life; the former deny any rights to the latter, who claim an absolute liberty for their own will. It is a world of bellum omnium contra omnes, where fear draws out contracts among people. ${ }^{19}$ The natural desire for self-preservation is the fundamental law of Nature. ${ }^{20}$

The appeal of the Hobbesian conception of human psychology to the libertines depended on its practical utility and congenial necessity. ${ }^{21}$ Wilson has asserted that, "They were interested in the subtleties of human relationships with their enclave, and they prized the interpretations of those relationships through the blend of fancy and judgement which they called Wit". ${ }^{22}$

In addition to this, Hobbesian and Epicurean ideas questioned the "effective denial of Natural law, the traditional Christian Deity and any clear sanctions governing human conduct". ${ }^{23}$ Hobbes's main aim, in his Leviathan, was to demonstrate that Religion was the real instrument of subservience, hidden behind the idea of the unity of religious power and political sovereignty in order to justify the king's supremacy. He asserted that people had to recognize the existence of God in the king's person. Obedience to him and to civil laws was the only means to reach salvation. ${ }^{24}$ From a different point of view, it was the only means to restrict and submit the Country to authority; thus, it involved a limitation of the satisfaction of desires, affirming men's weakness,

\footnotetext{
15 Ibidem.

16 J. H. Wilson. The court wits of restoration, op. cit., p. 18.

17 John Wilmot. (2002). Love a woman 11. 9-16. In Paul Hammond (Ed.), Restoration literature, an anthology. Oxford: Oxford University Press, p. 255.

18 W. Chernaik. Sexual freedom in restoration literature, op. cit., p. 34.

19 Ibid., p. 30.

${ }^{20}$ Ibid., p. 30 .

21 Ibidem.

${ }^{22}$ J. H. Wilson. A preface to restoration drama, op. cit., p. 168.

23 W. Chernaik. Sexual freedom in restoration literature, op. cit., p. 27.

24 Thomas Hobbes. (1970). Leviathan. London: Aldine Press, XLIII, p. 320.
} 
denying the natural liberty of man.

In being hostile to marriage, family, and Government, libertines were challenging the Stuart ideology. They worked to profess individual liberty, which involved a more permissive notion of sexual behaviour and individual conscience. Their idea of sex did not contemplate the reproductive capacity of women, pregnancy, or children. ${ }^{25}$

Both in libertine plays and in Hobbes' theory, "Happiness in material terms is the satisfaction of desire, the discharge of pent-up energy". ${ }^{26}$ In order to clarify his idea, the philosopher affirmed:

Continual successe in obtaining those things, which man from time to time desireth, that is to say, continual prospering, is that men call FELICITY; I mean the Felicity of this life. For there is no such thing as perpetual Tranquillity of mind, while we live here; because Life itself is but Motion and can never be without Desire, nor without Feare, no more than without Sense. ${ }^{27}$

According to the libertine philosophy, desire is the only driving force, a ceaseless pursuit of what cannot be fully achieved. Love is just another name sexual desire is called by which constantly requires to be satisfied.

For Hobbes, as for the Wits, material circumstances imprison man, who is a material being in rebellion; he fights to satisfy his endless longing, sexual desires, and thirst for power, till his end. ${ }^{28}$ Hobbes himself affirmed that he "put[s] for a generall inclination of all mankind, a perpetual and restlesse desire of Power after power, that ceaseth only in Death". ${ }^{29}$ It is the aspiration to power that makes for a constant conflict to obtain the same things.

Moreover, human desire, from an Epicurean point of view, is limitless, endless. It drives man to what Hobbes calls, in his Leviathan, constant rivalry. ${ }^{30}$ Appetite, sexual impulses, and sexual desires are "the motivating forces of man in society"; ${ }^{31}$ they are as natural as irresistible.

In the Restoration context, "the natural freedoms of natural lust depend, it seems, on a conception of natural order which is violated by the particular nature of sexual and social promiscuity of Restoration London. [...] but for women the rules were different". ${ }^{32}$

Restoration libertinism was basically predatory and misogynist, and the sexual liberation of the 1660s and 1670 s, as Goreau affirms, generated "a series of reaction which ultimately amounted to a counteraction of the original impulse" ${ }^{, 33}$ against certain women. As their male contemporaries, those women claimed their right to act and satisfy their sexual desires, ${ }^{34}$ but this contributed to reinforce the deep sense of male chauvinism. Furthermore, as Foucault argued, "Men think that women can only experience pleasure in recognizing men as masters". 35

\footnotetext{
${ }^{25}$ Susan Staves. (2004). Behn, women, and society. In Derek Hughes and Janet Todd (Eds), The Cambridge companion to Aphra Behn. Cambridge: Cambridge University Press, p. 21.

${ }^{26}$ W. Chernaik. Sexual freedom in restoration literature, op. cit., p. 32.

27 T. Hobbes. Leviathan, op. cit., VI, p. 30.

28 W. Chernaik. Sexual freedom in restoration literature, op. cit., p. 34.

29 T. Hobbes. Leviathan. op. cit., XI, p. 49.

${ }^{30}$ Ibid., XVII, p. 89.

${ }^{31}$ W. Chernaik. Sexual freedom in restoration literature, op. cit., p. 38.

32 Sarah Wintle. (1982). Libertinism and Sexual Politics. In Jeremy Treglown (Ed.), Spirit of wit, reconsiderations of Rochester. Hamden, Conn, Archon Books, p. 164.

33 Angeline Goreau. (1980). Reconstructing Aphra, a social biography of Aphra Behn. New York, The Dial Press, p. 182.

${ }^{34}$ Ibidem.

35 Michel Foucault. (1990). Politics, philosophy, culture: Interviews and other writings, 1977-1984. New York, Routledge, p. 300 .
} 
The idea in Wits' minds that woman might feel the same sexual desires as man was an unacceptable and an intolerable possibility. ${ }^{36}$ In their masculinist ideology, "A woman was a 'cunt' and any man who was foolish enough to respect her for any qualities was missing the point". ${ }^{37}$ This view contrasts with Hobbes' belief, which rejected woman's subordination. The philosopher recognized the real power to lie in Mother's hands, when she declares who her children's father is. She has the power and she is an independent being. Besides, as Susan Staves has argued:

Male libertine desire focuses narrowly on the pleasure of sexual intercourse in the present moment; it is a desire of conquest and the experience of power as well as for sexual orgasm. Hence, it is excited by resistance [...]. Female desire $[\ldots]$ entails an experience of powerlessness. [...] For woman, the experience of desire is simultaneously proof that she is desirable, threat to her separate identity and exciting because it has the power to destroy. ${ }^{38}$

In few words, libertine philosophy reduced women to object, a passive body, desiring the male in order to be complete. The reiteration of the male position in Society created the idea of male perfection and dynamism. This construction of gender was both the product and the process of its representation in the Restoration. ${ }^{39}$ It is the fruit of what Hélène Cixous calls "patriarchal binary thought", ${ }^{40}$ a cultural construction, turned into an automatic mechanism in people's mind distinguishing along binary oppositions between Activity/Passivity; Sun/Moon; Culture/Nature; Father/Mother; Day/Night; Head/Emotions; Intelligibility/Sensitive; Logos/Pathos. In this scheme, the feminine pole is always regarded as the negative one, a "powerless instance". ${ }^{41}$ She has underlined, using Derrida's concept of différance, that in order to affirm male's existence and power, it is necessary to destroy the other [the powerless instance]. ${ }^{42}$ She adds:

The "couple" cannot be left intact: It becomes a general battlefield where the struggle for signifying supremacy is forever re-enacted. In the end, victory is equated with activity and defeat with passivity; under patriarchy, the male is always the victor. ${ }^{43}$

That is what happened or what men tried to do in the seventeenth century: destroying women. But, significance of masculinity, according to Derrida, strengthens sapping the other's energy, annihilating or simply reducing the other, woman, to substance. Masculinity can be achieved only in this direct opposition to femininity. It is through this endless process of referring to the other, the absent signifier, that meaning is produced. ${ }^{44}$ It is the opposition of two realms, as Cixous argues, the realm of the Proper, where men dominate, and the realm of the Gift (woman's realm), that lies the most hopeful answer to the problem of woman's absence in the literary canon till now. ${ }^{45}$ She explains:

\footnotetext{
${ }^{36}$ A. Goreau. Reconstructing Aphra, op. cit., p. 183.

${ }^{37}$ Ibid., p. 170.

38 S. Staves. Behn, women, and society, op. cit., p. 22.

39 Teresa De Lauretis. (1987). Technologies of gender, essays on theory, film, and fiction. London, MacMillan, p. 5.

40 Toril Moi. (1985). Sexual/Textual politics: Feminist literary theory., London, Routledge, p. 104.

41 Ibidem

42 Ibid., p. 105.

${ }^{43}$ Ibidem.

44 Ibidem.

45 Hélène Cixous. (1981). Castration or decapitation? In Signs: Journal of Women in Culture and Society, vol. 7, no. 1, pp. 41-55.
} 
In the Realm of the Proper, the gift is perceived as establishing an inequality - a difference - that is threatening in that it seems to open up an imbalance of power. Thus the act of giving becomes a subtle means of aggression, of exposing the other to the threat of one's own superiority. ${ }^{46}$

It is evident that the apparent freedom given to women in late Stuart rule was only a myth. ${ }^{47}$ The public sphere and sexual behaviours were free enough, but that freedom was a male prerogative. Man was free to rove from an adventure to another only in the name of Desire. Women were only allowed to live their own private lives in the shadows of their domestic worlds.

The new feminine sexual freedom consisted essentially in the adoption of a cynical behaviour, typical of male libertines; a mistake could transform their advantage in their ruin. Female libertines, who adopted a similar behaviour to that of their male partners, reflecting them as a mirror image, constituted the principle subject of male disgust and of their cruel satire. ${ }^{48}$ What was remarkable for the man was a sin for the woman. As Chernaik has claimed, this "moral condemnation sounded quite odd coming from the mouth of a libertine". 49

The reopening of theatres in 1665 wanted by Charles II can be regarded as the best example of this season of weird contradictions. For the first time in English theatrical history, women were allowed to appear on the public stage, even if the Carolean society persisted in conceiving them only as wives or mistresses, as "Dark lady or female saint". 50

As Goreau pointed out, women could choose between two statuses.

Choosing to be a wife [...] usually meant lonely confinement in an isolated estate for the better part of one's life; it was customary for Restoration gentlemen [...] to do as they liked in libertine London [...].

Choosing to be a mistress, however, made one still more dependent [...] In a world where men accustomed to using women with ruthless egotism [...]. In order to survive in such a world, women had to renounce to love because it made too vulnerable in a predatory scheme where the law was to eat or to be eaten. ${ }^{51}$

This view is still quite naive. New "feminist" ideas tried to overcome this simplistic attitude. The lady cavaliers, or female Wits, who decided to embark on a different path, were stigmatised in life and after life, with the epithet of "whore". In this regard, Jane Spencer has argued that,

This has been as true of Aphra Behn as of other women writers, and it is not surprising that woman who in the relatively free atmosphere of the Restoration, wrote about sexual freedom, should have been attacked for her life as her writing during the moral clampdown of the eighteenth century. ${ }^{52}$

As active figures, they rejected passive stereotypes of woman, claiming their equality. Just as abusive as their male friends, as bawdy as their role required, they were depicted as vicious and degenerate. ${ }^{53}$ They did not want to be "the lady of the hearth", secluded in their homes, without any proper education and, any cultural or professional aspirations.

46 T. Moi. Sexual/Textual politics: Feminist literary theory, op. cit., p. 104.

${ }^{47}$ Susan J. Owen. (1996). Sexual Politics and party politics in Behn's drama, 1678-83. In Janet Todd (Ed.), Aphra Behn studies. Cambridge, Cambridge University Press, p. 154.

48 A. Goreau. Reconstructing Aphra, op. cit., p. 182.

49 S. Staves. Behn, women, and society, op. cit., p. 25.

${ }_{50}$ W. Chernaik. Sexual freedom in Restoration literature, op. cit., p. 117.

51 Ibidem, pp. 176-177.

52 Jane Spencer. (2000). Aphra Behn's after life. Oxford, Oxford University Press, p. 12.

53 A. Goreau. Reconstructing Aphra, op. cit., p. 183. 
In this respect, Margaret Cavendish lamented: "we are become like worms that only live in the dull earth of ignorance, winding ourselves sometimes out by the help of some refreshing rain of good education, which seldom is given us". 54

Women such as Aphra Behn, Nell Gwyn, and Elizabeth Barry obtained their fame because they dared to invade and violate an exclusive male territory: the theatre. Popularity on stage as dramatists, or actresses, went together with public consensus but critical disdain, too. They were famous but they were soon forgotten. As Jane Spencer argued, "the most extreme male reaction was to deny their ability to write" unclean, untidy, or simply whores. She adds that "In a female writer, bawdy expressions could be taken as evidence of an unchaste and therefore unacceptable woman; while knowledge of sexual irregularity in her life was used to condemn her writing as immoral". ${ }^{56}$

Another concept contributes to define Woman in the 1660s. It depicted two patriarchal ideas of woman, circulating in the Restoration period, one biblical and one secular. The lady cavaliers, or female Wits, dangled between them, rejected them or, as Aphra Behn did, accepted only a part of both, the one they were interested in. Janet Todd writes:

A woman [could be] seen through the misogyny of the Bible as the weaker vessel of Sin and Sex, and of a woman as a physical, emotional and intellectual entity distinct from man, ruled not by Eve's fault but by her oversensitive body. Aphra Behn was curiously, although not completely free from the first, while her antipathy for the second fuelled many of her irritated generalisations about women. ${ }^{57}$

Behn was continuously attacked for being a writer and because of her libertinism and success. Her writings achieved fame because she was good at doing it and not because she was one of the first female writers.

The most remarkable critique and, to some extent, what scandalized their contemporaries the most, was the fact that they professed to write because they needed money, they were "forced to write for Bread and not ashamed to owne it". ${ }^{58}$ This was shocking for the time. This led to a dominant attitude of associating the publication of women's writing with the exhibition of her body without any veils. Writing was a male prerogative. Women's writing was conceived as a trade good. Selling women's writing was soon equated with trading a sexual property. ${ }^{59}$ In other words, it was prostitution.

Aphra Behn was indeed accused of prostitution and of having exalted raging and indiscriminate sexual appetite. She had to fight against male virulent attacks. In 1691, Robert Gould, a misogynist critic, accused women writers of having broken "a silence prescribed by custom". 60

As I have already said, for the time it was a scandalous sexual transgression, an abominable behaviour for a good woman, who had the only duty to hide her inner thoughts. Writing was regarded as an extension of sexual activity where woman could play out her erotic power. She dared to share the secrets of her mind, worse, "If she

\footnotetext{
${ }^{54}$ Margareth Cavendish. (2000). Philosophical and physical opinions. In Janet Todd (Ed.), The secret life of Aphra Behn. London, New York, Sidney, Pandora, p. 22.

55 J. Spencer. Aphra Behn's after life, op. cit., p. 6.

56 Ibid., p. 24.

57 Janet Todd. (2000). The secret life of Aphra Behn. London, New York, Sidney, Pandora, p. 4.

58 Jane Spencer. (1986). The rise of the woman novelist, from Aphra Behn to Jane Austen. Oxford, Basil Blackwell, p. 28.

59 Catherine Gallagher. (1999). Who was that masked woman? The prostitute and the playwright in the comedies of Aphra Behn. In Janet Todd (Ed.), Aphra Behn (New casebooks). New York, St. Martin's Press, p. 16.

${ }^{60}$ W. Chernaik. Sexual freedom in Restoration literature, op. cit., p. 134.
} 
was married, she was selling what did not belong to her, because in mind and body she should have given herself to her husband". ${ }^{61}$ A good woman, who decided to write, as an immediate consequence lost her "virtue", 62 gaining access to the little but fantastic whore's world of women's literature.

It is in this context that Aphra Behn matured her ideology, recognizing, or rather claiming her androgynous, "masculine part". She was conscious of the conventional polarization of female vs. male in Restoration poetry, and of male supremacy, for that reason she claims:

All I ask, is the Privilege for my Masculine Part the Poet in me, (if any such you will allow me) to tread in those successful Paths my Predecessors have so long thriv'd in, to take those Measures that both the Ancient and Modern Writers have set me, and by which they have pleas'd the World so well: If I must not, because of my Sex, have this Freedom, but that you will usurp all to your selves; I lay down my Quill, and you shall hear no more of me, not so much as to make Comparisons, because I will be kinder to my Brothers of Pen, than they have been to a defenceless Woman; for I am not content to write for a Third Day only. I value Fame as much as I had been born a Hero; and if you rob me of that, I can retire from the ungreateful World and scorn its fickle Favours. ${ }^{63}$

In asking for a place among libertines and writers, Behn broke the rigid dichotomies of Restoration poetry, and she demanded to be equal to men. She possessed a male poetic gift, the "masculine part of Poet", 64 so she could be a writer.

Her sexual libertinism was opposed to Katherine Phillips' respectful writings. The opposition between these two contradictory paradigms of Women writers was offered: on the one hand, the reserved, austere mode of Katherine Philips, Orinda, who was considered as a chaste and less problematic model for women writers, ${ }^{65}$ especially because she was a poetess; on the other hand, Astrea, Aphra Behn, who was too frank, too bawdy but, especially, she imagined "strong, independent women making their own choices, women who may be viragoes, transvestites, or, most unconventionally, even courtesans. Behn balance[d] these images of female power with contrasting images of subjection, slavery, confinement, even physical handicap" 66

\section{Conclusion}

The Restoration of Charles II in 1660 marked a fundamental awareness in the English history characterised by the reintroduction of monarchy to a nation that was determining global events through its artistic, scientific, and intellectual achievements. This period was deeply influenced by the Puritan Age marking the strong connection between the two ages. The latter was the inevitable consequence of the former. It also brought to a new vision of the world where hobbesian ideas and libertinism had an outstanding role in the formation of the new politics. Nevertheless, this remains a period of strong contradictions where some questions remained unanswered.

${ }_{61}^{61}$ C. Gallagher. Who was that masked woman?, op. cit., p. 16.

${ }^{62}$ W. Chernaik. Sexual freedom in Restoration literature, op. cit., p. 134.

${ }^{63} \mathrm{~J}$. Spencer. The rise of the woman novelist, op. cit., p. 43.

${ }^{64}$ Ibidem.

65 Ibid., p. 29.

${ }^{66}$ Jacqueline Pearson. (1988). The prostituted muse, image of women \& women dramatists, 1642-1737. New York, London, Toronto, Sidney, Tokyo, Harvester-Wheatsheaf, p. 168. 


\section{References}

Chernaik, W. (1995). Sexual freedom in Restoration literature. Cambridge: Cambridge University Press.

Daiches, D. (1960). A critical history of English literature (Vol. III). London: Secker \& Warburg.

Hobbes, T. (1970). Leviathan. London: Aldine Press.

Mowry, M. M. (2004). The bawdy politic in Stuart England, 1660-1714, political pornography and prostitution. Burlington: Ashgate.

Peakman, J. (2003). Might lewd books: The development of pornography in eighteenth-century England. Houndmills: Palgrave Macmillan.

Styan, J. L. (1986). Restoration comedy in performance. Cambridge, London, New York: Cambridge University Press.

Trevelyan, G. M. (1964). Illustrated English social history (Vol. II). London: Pelican Books.

Turner, J. G. (1987). One flash: Paradisal marriage and sexual relations in the age of Milton. Oxford: Clarendon Press.

Turner, J. G. (2003). Libertines and radicals in early modern London: Sexuality, politics, and literary culture, 1630-1685. Cambridge: Cambridge University Press.

Webster, J. W. (2005). Performing libertinism in Charles II's court, politics, drama, sexuality. New York, Basingstoke, London: Palgrave McMillan.

Wilson, J. H. (1948). The court wits of Restoration, an introduction. Princeton: Princeton University Press.

Wilson, J. H. (1968). A preface to Restoration drama. Cambridge, Massachusetts: Harvard University Press.

Wintle, S. (1982). Libertinism and sexual politics. In J. Treglown (Ed.), Spirit of wit, reconsiderations of Rochester (pp. 133-165). Hamden, Conn: Archon Books. 